\title{
Intentions to buy a service: The influence of service guarantees, general information and price information in advertising
}

\author{
C. Boshoff* \\ Department of Business Management, University of Port Elizabeth \\ PO Box 1600, Port Elizabeth 6000, Republic of South Africa \\ ecahcb@upe.ac.za
}

Received November 2002

\begin{abstract}
Against the background of the challenge service marketers face in influencing the risk perceptions of service buyers, this study attempts to assess the impact three independent variables can have on potential service buyers' intentions to buy a service. The three independent variables were: providing general service information; providing price information; and providing a service guarantee. The empirical study was of an experimental nature and used a factorial design to assess the impact of different mock advertisements on intentions to buy. The 18 different advertisements showed different combinations of information, prices and three levels of service guarantees.
\end{abstract}

The empirical results indicate that combing all three of the independent variables (providing general service information, providing price information and providing a service guarantee) in printed advertising significantly enhances consumers' intentions to buy. Another important finding of this study is that an unconditional service guarantee is not as important as is often suggested in the service literature.

*To whom all correspondence should be addressed.

\section{Introduction}

Consumers' actual buying behaviour is heavily influenced by their perceptions and attitudes. Multi-attribute models of consumer behaviour reveal that attributes and salient beliefs (beliefs that are considered during a purchasing evaluation) are particularly influential (Solomon, 1992: 150). Perceived risk is an example of an attribute about which a consumer will hold a belief and that belief will impact on their buying behaviour. Due to the nature of services perceived risk is even more prevalent in services buying behaviour than buying a physical product (Mitchell \& Prince 1992:8).

Marketers can reduce risk in a variety of ways including providing general or specific information, gaurantees/warrantees, money-back offers, endorsements, branding and via a store image (Mitchell \& Boustani 1992:21; Solomon 1992:372; Hoffman \& Bateson, 1997:87). These risk reliever tactics can be divided into two broad categories: either minimising the consequences of product/service failure or by enhancing the certainty that the product/service will perform adequately. Consumer perceptions of both these tactical options, namely minimising the consequences of failure (providing a service guarantee) or by enhancing the certainty that the product/service will perform adequately (providing information) when advertising a service, is the focus of this study. In other words, we investigate whether risk perceptions can be reduced and whether the likelihood that a customer will buy a service can be enhanced in the process.
If one accepts that marketing communication is about exchanges to establish shared meaning between a company and its customers (Shimp, 2000:4), these twin objectives of lowering risk perceptions and thus enhancing the buying intentions of consumers can be achieved with advertising.

\section{Services buying}

Services, because of their essentially intangible nature are typically regarded as a riskier purchase than a physical product (Murray, 1991; Mitchell \& Prince 1992:8). Distinguishing between search, experience and credence attributes, Hoffman and Bateson (1997:85) argue that a large proportion of the properties of services (experience and credence attributes) can only be evaluated during and after the consumption process. In other words, service buyers only know what they have bought after the buying decision - which is obviously risky.

\section{Risk and service guarantees}

A factor that also contributes to services being perceived as riskier than a physical product is the absence of standardisation (Hoffman \& Bateson, 1997:84). Because of the high level of human involvement and human interaction the standardisation of a service is not only difficult but over time, probably impossible. To formalise the commitment to standardisation some have proposed the use of service guarantees to ' $\ldots$ promise customers that service will be more consistent than is typically true in services ...' (Zeithaml \& Bitner, 1996:459). A service guarantee is thus a means of reducing potential service buyers' anxiety and 
uncertainty prior to an actual purchase which should enhance potential buyers' intention to buy. Many argue that such a guarantee must be unconditional (Hart, 1988) with no 'strings attached'.

\section{Risk and general information}

Some have argued that the higher risk levels associated with buying a service is due to the limited information available to service buyers (Hoffman \& Bateson, 1997:85). By implication risk can be reduced by supplying more information to service buyers. Consumers differ in the amount of information they seek prior to purchase (Solomon, 1992:247), depending on factors such as knowledge and previous experience. High-risk perceptions increase the amount of information search consumers do (Solomon, 1992:253) and services buyers in particular do demand relatively higher levels of information (Deshpande \& Krishnan, 1977). Often consumers use mass media advertising as a means of collecting information and reducing risk perceptions (Garner, 1986:55; Mitchell \& Greatorex, 1993:197).

Different perceptions of risks impact differently on the volume and sources of communication consumers use to collect pre-purchase information (Solomon, 1992:253). For instance, the higher the perceived risk associated with the purchase of a product or service, the more information is a potential customer likely to collect prior to the actual purchase (Solomon, 1992: 251). In other words, as the volume of information collected increases perceived risk decreases (Lutz \& Reilly, 1973) which should lead to higher intentions to buy.

\section{Risk and price information}

Price is an important type of information services marketers can supply to prospective buyers. Price influences the prospective buyer's expectations of service levels. A too low price, for credence products in particular, may suggest inferior quality (Zeithaml \& Bitner, 1996:491) and thus high risk. Hoffman and Bateson (1997:69), for instance, argue that service buyers are prepared to pay more for a service to reduce the uncertainty associated with unfamiliar service providers. Because potential consumers perceive a service as a riskier purchase than a physical product, they often use physical cues (or evidence) as a means of assessing a service prior to buying. Prices are '.. a visible indicator of a service's level and quality' (Berry \& Parasuraman, 1991:102) and thus as a means of reducing perceived risk (Berry \& Parasuraman, 1991:113). By implication access to price information will enhance potential buyers' intention to buy

Services marketers can thus use several strategies to reduce risk perceptions and to indirectly enhance the purchase intentions of prospective buyers. Examples are providing potential buyers with general information about the service, by providing potential buyers with price information and by providing potential buyers with a service guarantee prior to actual purchase. This relationship is depicted below:

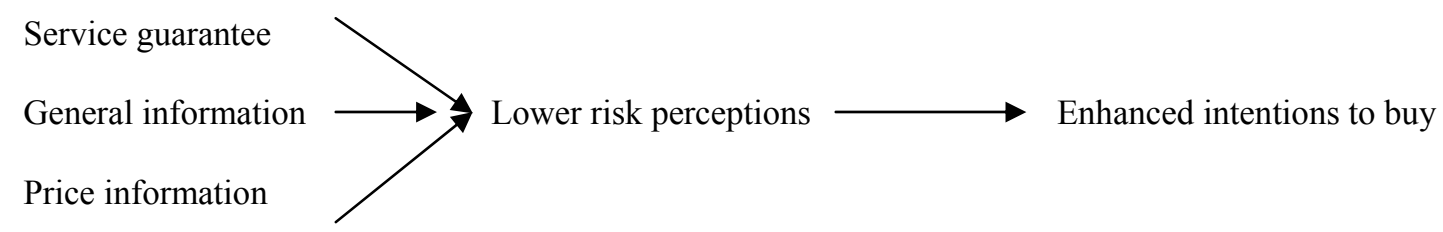

\section{Objective}

Considering the challenge service marketers face in influencing the risk and other perceptions potential services buyers have, this study attempts to assess the impact three independent variables can have on potential service buyers' intentions to buy a service namely: providing general service information, providing price information and providing a service guarantee. The dependent variable is thus intentions to buy. To address the objective a service with considerable experience attributes, namely an overseas holiday, was chosen as focus of the study.

\section{The hypotheses}

Based on the preceding literature review the following hypotheses were tested:

$\mathrm{H} 0^{1}$ For a service with high experience qualities the provision of a service guarantee will enhance intentions to buy
$\mathrm{H}^{2}$ For a service with high experience qualities the provision of general information will enhance intentions to buy

$\mathrm{H} 0^{3}$ For a service with high experience qualities the provision of price information will enhance intentions to buy

\section{Methodology}

The study tested the formulated hypotheses using a $3 \mathrm{X} 3 \mathrm{X} 2$ between-subject factorial design. Respondents were randomly assigned to one of the 18 conditions. Respondents were randomly stopped in a shopping mall environment and asked to participate in the study. A screening question was asked first, however. Only those who have been on a holiday on a sub-tropical island such as Hawaii, Mauritius or Fiji during the preceding six months were allowed to participate in the study. The objective of the screening question was merely to ensure that all respondents were familiar with the product category and that experience was, at least to some extent, held constant. Following this screening question, interviewers presented them with a travel scenario: you want to go on an island holiday, you 
have saved enough money, this is the price. For the same price you can go to a new hotel (introduction of risk) on a recently discovered island (same travelling time and same price as the other more conventional, better known options). They were asked to imagine that they were a potential tourist in the scenario and then shown one of 18 different printed advertisements of the new hotel on the new island. The 18 different advertisements showed different combinations of information (full, limited, no information), price at two levels (price, no price) and three levels of service guarantees (unconditional guarantee, conditional guarantee, no guarantee).

\section{The sample}

As 30 responses were required for each of the 18 cells (scenarios), 540 randomly selected "experienced" tourists were interviewed.

\section{The measurements}

Intentions to buy were measured with two ordinally scaled items. The first item read:

How likely are you to change your booking to that of the new hotel? The question was linked to a 7-point semantic differential scale anchored by 'extremely likely' (value 7) and 'extremely unlikely' (value 1). The second question read: 'When you enter the travel agent's office soon afterwards, she asks: 'Are you packed for ...(island's name)...?' What is you answer most likely to be? This question was also linked to a 7-point semantic differential scale anchored by 'definitely, yes' (value 7) and 'definitely, no' (value 1). Each scenario was linked to a mock advertisement as used previously by Erevelles (1993:174). The different treatments and levels incorporated in the different advertisements were: information (full, limited, no information); price at two levels (price, no price); and three levels of service guarantees (unconditional guarantee, conditional guarantee, no guarantee).

\section{The advertisements}

In an effort to enhance face validity all 18 advertisements were typical of the ones used to advertise hotel holidays on exotic islands.

\section{Statistical analysis}

An Analysis of Variance (ANOVA) procedure was used and then followed up with Duncan's Multiple Range test when appropriate.

\section{Empirical results}

\section{Main effects}

According to Table 1 a service guarantee is the only independent variable that would, on its own, exert a significant $(p<0.05)$ impact on intentions to buy. In other words, on its own providing general information and price information will not influence consumers' intentions to purchase a risky service. $\mathrm{H}^{1}$ is thus accepted but $\mathrm{H}^{2}$ and $\mathrm{H} 0^{3}$ can not be accepted.

\section{The interaction effects}

Combining the different independent variables will, however, influence intentions to buy. Combining a service guarantee with general information and price information will significantly $(\mathrm{p}<0.001)$ influence consumers' intentions to purchase a risky service. Combining general information with price information $(\mathrm{p}<0.01)$ and a service guarantee with price information $(\mathrm{p}<0.01)$ in an advertisement will also significantly enhance intentions to buy a risky service. Providing a service guarantee and general information will however, have no impact.

For the same reasons as mentioned earlier the differences between the mean scores of the two-way interactions were analysed using Duncan's Multiple Range test.

\section{The two-way interactions}

\section{Service guarantee and price}

Table 2 shows that the intentions to buy mean scores do not differ significantly when only general information is provided in an advertisement whilst manipulating different types of service guarantees. In other words, if a service marketer does not provide prices in an advertisement it does not matter (to intention to buy) whether no service guarantee is offered, nor whether a conditional or unconditional guarantee is provided. However when a price is included, a conditional service guarantee significantly $(\mathrm{p}<0.05)$ enhances intentions to buy (from 3.64 to 4.69). The difference between a conditional guarantee (4.69) and an unconditional guarantee (4.45), however, not statistically significant. In other words, when a price is provided an unconditional service guarantee fares no better in enhancing intentions to buy than a conditional one. An unconditional service guarantee (4.45) is, however, significantly more advantageous than no guarantee at all (3.64).

Table 2 also shows that when no price is included in an advertisement it does not matter (in terms of intentions to buy) whether no information is provided (4.55) or whether limited information is provided (4.75). However, when no price is provided detailed information in an advertisement significantly reduces intention to buy (when compared to only limited information (decreases from 4.75 to 3.89 ).

When the advertisement does specify a price there is no difference in intentions to buy between no information provided (4.03) and limited information provided (3.89). However, providing detailed general information (4.86) enhances intentions to buy significantly $(\mathrm{p}<0.05)$ more than either no information (4.03) and only limited information (3.89), provided the price is specified in the advertisement. 
Table 1: Analysis of variance results

\begin{tabular}{|c|c|c|c|c|}
\hline \multicolumn{5}{|c|}{ Dependent variable: INTENTIONS TO BUY } \\
\hline Main effects & Mean square & df & $\mathbf{F}$ & pvalue \\
\hline Serviceguarantee & 11,97 & 2 & 3,18 & 0,0423 \\
\hline Information & 0,32 & 2 & 0,09 & 0,9185 \\
\hline Price & 2,40 & 1 & 0,64 & 0,4247 \\
\hline \multicolumn{5}{|l|}{ Twowayinteractions } \\
\hline & & & & \\
\hline Serviceguarantee $\mathrm{x}$ price & 13,34 & 5 & 3,77 & 0,0023 \\
\hline $\begin{array}{l}\text { Serviceguarantee } \mathrm{x} \\
\text { information }\end{array}$ & 4,55 & 8 & 1,29 & 0,2479 \\
\hline Information $\mathrm{x}$ price & 17,63 & 8 & 4,98 & 0,0002 \\
\hline \multicolumn{5}{|l|}{ Threewayinteraction } \\
\hline $\begin{array}{l}\text { Serviceguarantee } \mathrm{x} \\
\text { info } \mathrm{x} \text { price }\end{array}$ & 10,82 & 17 & 3,05 & 0,0001 \\
\hline
\end{tabular}

10,82

Table 2: Duncan's multiple range test results: two way interactions

\section{Dependent variable: INTENTIONS TO BUY}

\section{Two-way interaction: Service guarantee $x$ information}

No information $\mathrm{x}$ no service guarantee

No information $\mathrm{x}$ conditional service guarantee

No information $\mathrm{x}$ unconditional service guarantee

Limited information $\mathrm{x}$ no service guarantee

Limited information $\mathrm{x}$ conditional service guarantee

Limited information $\mathrm{x}$ unconditional service guarantee

Detailed information $\mathrm{x}$ no service guarantee

Detailed information $\mathrm{x}$ conditional service guarantee

Detailed information $\mathrm{x}$ unconditional service guarantee

\begin{tabular}{|c|c}
\hline & Mean \\
\hline & \\
\hline 4,03 & 2,13 \\
\hline 4,50 & 2,21 \\
\hline 4,35 & 1,68 \\
\hline 4,14 & 1,96 \\
\hline 4,45 & 2,13 \\
\hline 4,38 & 1,64 \\
\hline & \\
\hline 3,95 & 1,82 \\
\hline 4,31 & 1,93 \\
\hline 4,87 & 1,84 \\
\hline
\end{tabular}

\section{Two-way interaction: Service guarantee $\mathrm{x}$ price}

No price $\mathrm{x}$ no service guarantee

No price $\mathrm{x}$ conditional service guarantee

No price $\mathrm{x}$ unconditional service guarantee

Price provided $\mathrm{x}$ no service guarantee

Price provided $\mathrm{x}$ conditional service guarantee

Price provided $\mathrm{x}$ unconditional service guarantee

\begin{tabular}{l|l}
\hline 4,43 & 1,99 \\
\hline 4,14 & 2,12 \\
\hline 4,61 & 1,72 \\
\hline & \\
\hline $3,64^{\mathrm{a}}$ & 1,89 \\
\hline $4,69^{\mathrm{b}}$ & 2,00 \\
\hline $4,45^{\mathrm{c}}$ & 1,78 \\
\hline
\end{tabular}

\section{Two-way interaction: Information level $x$ price}

\footnotetext{
No price $\mathrm{x}$ no information

No price $\mathrm{x}$ limited information

No price $\mathrm{x}$ detailed information

Price provided $\mathrm{x}$ no information

Price provided $\mathrm{x}$ limited information

Price provided $\mathrm{x}$ detailed information
}

\begin{tabular}{|c|c}
\hline 4,43 \\
\hline 4,14 \\
4,61 \\
& $3,64^{\circ}$ \\
$4,69^{b}$ \\
$4,45^{\complement}$
\end{tabular}

\begin{tabular}{l|l}
\hline $4,55^{\mathrm{d}}$ & 2,05 \\
\hline $4,75^{\mathrm{e}}$ & 1,88 \\
\hline $3,89^{\mathrm{f}}$ & 1,86 \\
\hline & \\
\hline $4,03^{\mathrm{g}}$ & 1,99 \\
\hline $3,89^{\mathrm{h}}$ & 1,86 \\
\hline $4,86^{\mathrm{i}}$ & 1,82 \\
\hline
\end{tabular}

NOTE: a differs significantly from $\mathrm{b}$ and c; f differs significantly from e and d; i differs significantly from $\mathrm{h}$ and $\mathrm{g}$. All differences significant at the $5 \%$ level. 


\section{Summary of empirical findings}

The empirical results reported in Tables 1 and 2 can be summarised as follows:

When the objective of an advertisement is to enhance intentions to buy:

- no amount of general information combined with a service guarantee will influence intentions to buy;

- if the price of the service is not provided, an advertisement providing a service guarantee will not influence intentions to buy;

- $\quad$ if the price of the service is provided, a conditional service guarantee will significantly enhance intentions to buy, but an unconditional service guarantee will not lead to any further change in intentions to buy;

- if the price of the service is not provided, detailed additional general information about the service leads to a decrease in intentions to buy;

- if the price of the service is provided, additional general information about the service does lead to enhanced intentions to buy.

\section{Managerial implications}

If service marketers wish to enhance intentions to buy, combining a service guarantee with different levels of information will not be successful (Table 1). Providing a service guarantee combined with price information will, however, enhance intentions to buy (Table 1).

A conditional service guarantee combined with the price of the service will be the most optimal combination ('intentions to buy' mean $=4.69$ ) as an unconditional service guarantee does not add significantly to customers' intentions to buy (Table 2). In other words an advertisement that says: 'The price is $R$..... If you are not completely satisfied with your stay and La Palma is to blame, we will refund a part of your money, subject to mutual agreement' will be the optimal combination to enhance intentions to buy.

If a service marketer is unwilling or unable to provide a service guarantee, intentions to buy can be enhanced by combining price information and general information (Table 2). An advertisement that says: "The price is $R$....... La Palma is a brand new island resort located on an island close to Mauritius/Fiji/Hawaii. It boasts 120 airconditioned bedrooms, a swimming pool, two restaurants and white, sandy beaches. It offers all the amenities and water sports you can think of, including: a tennis court, a squash court, scuba diving, water-skiing, windsurfing and fishing - and its all included in the price' will be the optimal combination to enhance intentions to buy.

An important finding of this study is that an unconditional service guarantee is not as important as is often suggested in the service literature (Hart 1988). A conditional service guarantee can be just as effective in influencing consumers' intentions to buy - provided the advertising contains other relevant information, such as general information and price information.

\section{References}

Berry, L.L. \& Parasuraman, A. 1991. Marketing services: Competing through quality. New York: The Free Press.

Bitner, M.J. 1990. 'Evaluating service encounters: The effect of physical surroundings and employee responses', Journal of Marketing, 54 (2): 69-82.

Deshpande, R. \& Krishnan, S. 1977. 'A consumer-based approach for establishing priorities in consumer information programs: Implications for public policy, in contemporary marketing thought'. In Greenberg, B.A. \& Bellenger, D.N. (Eds.). Proceedings of the 1997 American Marketing Conference. Chicago: AMA, pp. 338-343.

Erevelles, S. 1993. 'The price-warranty contract and product attitudes', Journal of Business Research, 27: 171-181.

Garner, S.J. 1986. Perceived risk and information sources in services purchasing', The Mid-Atlantic Journal of Business, 24(2): 49-58.

Hart, C.W.L. 1988. 'The power of unconditional service guarantees', Harvard Business Review, (July-August):.5462.

Hoffman, K.D. \& Bateson, J.E.G. 1997. Essentials of services marketing. London: The Dryden Press.

Lutz, R.J. \& Reilly, P.J. 1973. 'An exploration of the effects of perceived social and performance risk on consumer information acquisition'. In Ward, S. \& Wright, P. (Eds.). Advances in consumer research, Vol 1. Urbana, Illinois: Association for Consumer Research, pp. 393-405.

Mitchell, V.W. \& Boustani, P. 1992. 'Consumer risk perceptions in the breakfast cereal market', British Food Journal, 94(4):17-26.

Mitchell, V.W. \& Greatorex, M. 1993. 'Risk perception and reduction in the purchase of consumer services', The Services Industries Journal, 13(4): 179-200.

Mitchell, V.W. \& Prince, G.S. 1992. 'Last buy and no effect on risk perception and reduction', Management Research News, 15(10):6-17.

Murray, K.B. 1991. 'A test of services marketing theory: Consumer information acquisition activities', Journal of Marketing, 55(1):10-25.

Shimp, T.A. 2000. Advertising promotion: Supplemental aspects of integrated marketing communication. London: The Dryden Press.

Solomon, M.R. 1992. Consumer behavior. London: Allyn and Bacon. 
Zeithaml, V.A., Parasuraman, A. \& Berry, L. 1985.

'Problems and strategies in services marketing', Journal of Marketing, Spring, 49:33-46.

Zeithaml, V.A., Parasuraman, A. \& Berry, L. 1990.

Delivering quality service. New York: The Free Press.

Zeithaml, V.A. \& Bitner, M.J. 1996. Services marketing. New York: McGraw-Hill. 